\title{
Family Ties and Political Participation
}

\section{Citation}

Alesina, Alberto, and Paola Giuliano. 2011. "Family Ties and Political Participation." Journal of the European Economic Association 9 (5) (May 18): 817-839. doi:10.1111/ j.1542-4774.2011.01024.x. http://dx.doi.org/10.1111/j.1542-4774.2011.01024.x.

\section{Published Version}

10.1111/j.1542-4774.2011.01024.x

\section{Permanent link}

http://nrs.harvard.edu/urn-3:HUL.InstRepos:30752839

\section{Terms of Use}

This article was downloaded from Harvard University's DASH repository, and is made available under the terms and conditions applicable to Open Access Policy Articles, as set forth at http:// nrs.harvard.edu/urn-3:HUL.InstRepos:dash.current.terms-of-use\#OAP

\section{Share Your Story}

The Harvard community has made this article openly available.

Please share how this access benefits you. Submit a story.

Accessibility 


\title{
Family Ties and Political Participation*
}

\author{
Alberto Alesina and Paola Giuliano \\ Harvard University, Igier Bocconi and UCLA
}

April 2009

\begin{abstract}
We establish an inverse relationship between family ties, generalized trust and political participation. The more individuals rely on the family as a provider of services, insurance, transfer of resources, the lower is civic engagement and political participation. The latter, together with trust, are part of what is known as social capital, therefore in this paper we contribute to the investigation of the origin and evolution of social capital over time. We establish these results using within country evidence and looking at the behavior of immigrants from various countries in 32 different destination places.
\end{abstract}

*Prepared for the JEEA lecture, American Economic Assocition meeting, January 2008. We thank Dorian Carloni and Giampaolo Lecce for excellent research assistanship. 


\section{Introduction}

Well functioning democracies need citizens' participation in politics. Political participation is a broader concept than simply voting in elections and it includes a host of activities like volunteering as an unpaid campaign worker, debating politics with others and attending political meetings like campaign appearances of candidates, joining political groups, participating in boycott activities, strikes or demonstrations, writing letters to representatives and so on. ${ }^{1}$ What determines it?

The purpose of this paper is to investigate an hypothesis put forward by Banfield (1958) in his study of a Southern Italian village. He defines "amoral familism" as a social equilibrium in which people trust (and care about) exclusively their immediate family, expect everybody else to behave in that way and therefore (rationally) do not trust non family members and do not expect to be trusted outside the family ${ }^{2}$. He argues that "amoral familism" leads to low civic engagement, low political participation and low generalized trust and confidence in political institutions. As a result "amoral familism" prevented the development of well functioning political institutions, created a situation where politics was simply a private affair of those who controlled it; common goods were completely disregarded and there was very little interest in participating in public affairs. In a similar vein, Putnam (1993) put forward the idea that a national culture of strong family ties generates distrust in government and parties. He also shows that these attitudes are extremely persistent. He documents that in the regions of Italy where civic participation was low during past decades, this participation did not increase significantly when the political system decentralized, showing a strong persistence in political dissatisfaction. This author goes back to events several hundred years old in Italian history to explain these different attitudes.

In the present paper, we combine Putnam argument with Banfield story attributing the dissatisfaction of political life and the low level of generalized trust to family ties. This lack of political participation and generalized trust is transmitted from parents to children: once acquired, political attitudes are particularly stable and tend to remain fairly stable over time. Attitudes of dissatisfaction with politics do not vary with the fortunes of specific parties or candidates. In societies where trust is built overwhelmingly on the family, modern democracy will face especially significant challenges if these negative attitudes towards politics are transmitted from one generation to the next.

In Alesina and Giuliano (2007) we measured the strength of family ties, that is the extent to which in different cultures family members are closely tied together, using answers to survey questions. Amoral familism would be the (pathological) extreme in the direction of strong family ties, so strong that

\footnotetext{
${ }^{1}$ Needless to say political participation can turn negative or even disastrous, just think of insurrections which destroy democracy itself.

${ }^{2}$ It is indeed not a coincidence that Italian mafia clans identify themselves as "families"; trust within a family is a "must" and complete distrust for outsiders is a key ingredient of the mafia organization. See Gambetta (1990).
} 
they are the "only" social connection which matters. In the present paper we successfully test the idea that political participation and civic engagement are inversely related to the closeness of family ties. Even casual observations point in the direction of a correlation between strength of family ties and civic engagement. In Northern European cultures, family ties are relatively low and social capital, trust and political participation are high; the opposite holds for Southern European cultures. A comparison of Northern and Southern Italy, a widely studied country in the literature on social capital, points to the same direction ${ }^{3}$.

But, of course we go beyond these casual observations. First we establish an inverse relationship between family ties and generalized trust. That is, the more one can trust only family members the lower is generalized trust; in other words strong family ties lead to a reduction in social capital. Then we establish a negative correlation between the strength of family ties and political participation. The intuition is that the more people rely on the family as a provider of services, insurance, transfer of resources, the lower is civic engagement and political participation. The more the family is all that matters for an individual the less he/she will care about the rest of society and the polity. Political participation, trust, and civic engagement are part of what is known as social capital, therefore in this paper we contribute to the investigation of the origin and evolution of social capital over time, a topic investigated in particular by Putnam (1983, 2000) and Guiso, Sapienza and Zingales (2007).

Cultural values like the strength of family ties can be explanatory variables of political participation if they are relatively slow moving. In fact, cultural values like the structure of the family are very stable over time as shown in many different ways by Alesina and Giuliano (2007), Bertrand and Schoar (2006), Reher (1998) and Todd (1985). The transmission of values regarding the family relies on parents-children relationship: parents teach children values about trusting the family only or trusting others more generally for instance. For a recent discussion see Tabellini (2008) and Bisin and Verdier (2001).

We gather our evidence in two ways. One is using the World Value Survey. We compare the effect of family ties within countries (i.e. we always have country fixed effects in addition to time dummies). Thus we do not rely on capturing, say the differences between the average Norwegian and the average Italian, a comparison which may be affected by a host of other variables which differentiate the two countries.

The second source of evidence is a comparison of political participation among second generation immigrants in 32 different destination countries. The approach of studying immigrant behavior has been used in a growing literature on the economic effects of culture. Alesina and Giuliano (2007), Algan and Cahuc (2009), Blau (1992), Carroll et al. (1994), Fernandez and Fogli (2009), Giuliano (2007) and Luttmer and Singhal (2009) analyze the behavior of immigrant groups to determine the effects of culture on female labor

\footnotetext{
${ }^{3}$ Orizo (1996) also finds that in Spain the great majority of youth expresses little interest in politics or in belonging to political organisations.
} 
force participation, trust, fertility, savings, geographical mobility, preferences for redistribution among many others ${ }^{4}$. Rather than using the United States as unique destination country, in this paper we look at immigrants coming not only from multiple source countries, but also going to multiple destination countries. By comparing the relationship between family ties and political participation of immigrants with different origin we further eliminate any effect emerging from making cross country comparisons. By looking at immigrants going to multiple destination countries, we also limit the scope for selection bias since we would expect the form of selection to differ across different destination countries. ${ }^{5}$

Political participation is obviously not affected only by family ties; many other factors are important. In particular we find that education is strongly positively associated with participation, a result in line with Glaeser, Ponzetto and Shleifer (2007) who stress the importance of education for maintaining democratic institutions. Many other individual characteristics are in line with what found on trust by Alesina and La Ferrara $(2002)^{6}$. There is also a vast literature in political science on what determines turnout in elections (see Merlo (2006) and Wolfinger and Rosenstone (1980) for a review) but our emphasis here is not specifically on turnout but on a broader definition of political engagement.

Before going any further we should stress that we are not implying that family ties (perhaps with the exception of the extreme case of amoral familism) are "bad". Closely connected families provide a host of home produced goods and services which are of great value for family members, and it is not at all clear that life satisfaction is lower with close family ties. In fact in Alesina and Giuliano (2007) we present some evidence that shows that indeed life satisfaction may be positively associated with strong family ties. This shows that the effect of family relationships is complex and not unidirectional. Strong or weak family ties are neither "bad" or "good" but they lead to different organizations of the family and have different social implications. ${ }^{7}$ In this paper we investigate the effects of family ties on political participation. Interestingly, to the extent that in some cases political participation may turn "ugly" it would be interesting to check whether stronger family ties also imply fewer instances of negative or hateful forms of political participation. Todd (1985) argues that indeed certain types of family structures are more or less compatible with more or less desirable forms of political organization like dictatorships versus liberal democracies. Further investigation of this point is left for future research.

The paper is organized as follows. In the next section we describe our data and our measures of family ties and of political participation. In Section 3 we present international evidence based upon the World Value Survey. In Section 4 we focus on immigrants. The last section concludes.

\footnotetext{
${ }^{4}$ See also the survey by Guiso et al. (2006) on the role of culture on economic outcomes.

${ }^{5}$ Note that to the extent that different cultures have different level of preferences for active political participation, changes in the composition of the pool of immigrants may at least in part explain the reduction in participation in social activities pointed out by Putnam (2000).

${ }^{6}$ The same authors (Alesina and La Ferrara (2004)) investigate the effect of racial fragmentation on participation in social activities finding a negative correlation between the two.

${ }^{7}$ See Esping Andersen (1999) for an illustration of the role of the family in different cultures as a provider of social insurance.
} 


\section{Empirical strategy}

\subsection{Data description}

We use two data sets, the World Value Survey and the European Social Survey. The World Value Survey (WVS) is a compilation of national surveys on values and norms on a wide variety of topics, carried out four times (1981-84, 19901993, 1995-97 and 1999-2004.) The coverage varies depending on the wave. The 1981-1983 survey covered 22 countries, the 1990-1993 wave 42, the 1995-1997 wave 54 and, finally the last wave covered 81 countries. The questionnaires contain information on different types of attitudes, religion and preferences, as well as information on standard demographic characteristics (sex, age, education, labor market status, income, etc.)

We also use data from three rounds of the European Social Survey (ESS), a biennial cross-sectional survey administered in a large sample of mostly European nations. The survey was conducted in three waves, in 2002/2003, 2004/2005 and 2006/2007. Thirty-two countries participated in at least one round of the survey (22 in the first, 26 in the second and 25 in the last one). The list of countries for both the World Value Survey and the European Social Survey, together with the demographic characteristics of our sample for both surveys are given in Appendix, Tables 4, 5, 6 and 7 .

For the European Social Survey our primary sample consists of immigrants; we define immigrants as individuals born in a certain country but whose fathers were born abroad. We associate to each immigrant the level of family ties in the home country as measured by the average at the country level calculated in the World Value Survey database. Summary statistics for second generation immigrants are provided in Appendix, Tables 7 and 8. The sample provides at least 13 observations per country of origin. The most representative groups come from the Russian Federation (850 observations), followed by Germans, Italians and Turkish. The respondents in our sample of second-generation are on average 48 years old, 45 per cent are men, $14 \%$ of them have only primary education, $5 \%$ of them are unemployed, $52 \%$ out of the labor force, with an average family income of $5.90^{8}$. Demographic characteristics and variables on political participation, trust and attitudes toward society of immigrants are not statistically different from those of natives.

Table 8 in the Appendix, also reports summary statistics of demographic variables and political participation of immigrants by country. There is a lot of heterogeneity across immigrant groups: Northern European countries tend to have a higher level of trust and more interest in political participation. Southern European groups are among the groups with the lowest level of trust and lower interest in politics. Eastern European countries lie somewhere in between, on the one hand they do show a low level of trust, on the other they do have a higher interest in politics. Income level also varies a lot with Russian and immigrants from Latvia in the lowest range and immigrants from Northern Europe, the UK

\footnotetext{
${ }^{8}$ Family income is coded on a scale from 1 to 12 . A level of income equal to 6 corresponds to an annual income between 18000 and 24000 euros.
} 
and Canada among the richest.

\subsubsection{A measure of family ties}

We measure the strength of family ties by looking at three WVS variables capturing beliefs on the importance of the family in an individual's life, the duties and responsibilities of parents and children and the love and respect for one's own parents. The first question assesses how important the family is in one person's life and can take values from 1 to 4 (with 1 being very important and 4 not important at all). The second question asks whether the respondent agrees with one of the two statements (taking the values of 1 and 2 respectively): 1) Regardless of what the qualities and faults of one's parents are, one must always love and respect them, 2) One does not have the duty to respect and love parents who have not earned it. The third question prompts respondents to agree with one of the following statements (again taking the values of 1 or 2 respectively): 1) It is the parents' duty to do their best for their children even at the expense of their own well-being; 2) Parents have a life of their own and should not be asked to sacrifice their own well being for the sake of their children.

We combine these measures in two ways. First we take the sum of all of them; we recode the variables in a way that a higher number corresponds to stronger family ties. Second, we extract the first principal component from the whole data set with all individual responses for the original variables. Figure 1 displays the values of our measure of the strength of family ties (expressed using the first principal component) at the country level. The ranking of the different countries is broadly consistent with perceptions and insights from the sociological and political science literature. Germany, Netherlands and the Northern European countries are the countries with the weakest ties, while African, Asian and Latin American countries lie in the lowest range. Among OECD countries, we find that Poland, US, Canada and Southern European countries (with the somewhat surprising exception of Greece) are among the countries with the strongest ties, while as before Northern Europe, Netherlands and Germany are the group with the weakest ties. Note that the US is an average of very different levels of family ties depending on the origin of the members of the "melting pot". The weak family ties of many Central and Eastern European former communist countries may be the result of Communist collectivist ideology and propaganda (see Alesina and Fuchs-Schulden (2007)). ${ }^{9}$ The analysis that follows, however, will use only within country-evidence.

\footnotetext{
${ }^{9}$ One may wonder how these regional averages relate to economic development. We also plot the residuals of a regression of family ties on the level of development of a country. The regional order remains the same, with two exceptions: Southern Europe shows stronger family ties than Latin America; moreover Eastern European countries appear to have weaker ties than Northern Europeans, indicating that GDP per capita is not what is driving our results.
} 


\subsubsection{Dependent Variables}

Political attitudes The first group of variables contains measures of political participation, such as general interest in politics and a variety of other indicators of political action. Interest in politics is measured by the following three questions. Variable 1, which we label "discuss political matters" is based on the following question: "When you get together with your friends, would you say you discuss political matters frequently, occasionally or never?" The variable takes the values of 3 if participants report Frequently, 2 if they answer Occasionally and 1 if the answer is Never. Variable 2, "Are you currently doing unpaid voluntary work for political parties or groups?" is equal to 1 if the answer is Yes and 0 Otherwise. The third variable indicates the general interest of the person in politics and it is phrased as follows: "How interested would you say you are in politics?" and the answer could take the following four values: Very interested (4), Somewhat interested (3), Not very interested (2) and Not at all interested (1).

Political action is measured by looking at the following questions: "Now I am going to read out some different forms of political action that people can take, and I would like to tell me, for each one, whether you have actually done any of these things, whether you might do it or would never, under any circumstances, do it", where the forms of political action are i) signing a petition, ii) joining in boycotts, iii) attending lawful demonstrations, iv) joining unofficial strikes and v) occupying buildings or factories. The answer for each form of political action could take the following three values: Have done (3), Might do (2) and Would never do (1). Note that each question is asked independently from another, meaning the respondent is not supposed to respond at the same time about the different forms of political participation.

Inward-looking attitudes According to Banfield and Putnam, we should expect a strong association between family ties and the level of trust for his/her own family, but a lower association with the level of generalized trust. This was the essence of amoral familism. In order to capture these cultural features of strong family ties, we consider the following questions. As a measure of trust, the question is "Generally speaking, would you say that most people can be trusted or that you can't be too careful in dealing with people?" The answer could be either Most people can be trusted (1) or Can't be too careful (0). To measure the trust in the family, we use the following question: "Could you tell me how much you trust your family?", where the answer could take the following values: Trust them completely (5), Trust them a little (4), Neither trust or distrust them (3), Do not trust them very much (2), and Do not trust them at all (1).

In studying the village of Chiaromonte in Southern Italy, Banfield (1958) was also struck by the reluctance to change and resignation of the peasants of that village so completely different from the attitudes of similar communities in the US. The author also mentions that in these societies the role of parental education is to teach children obedience, as nothing good usually comes from 
individual initiatives. To captures these cultural features of strong family ties, we consider the following questions. As a measure of reluctance to change we choose the following question: "On this card are three basic kinds of attitudes concerning the society we live in. Please choose the one which best describes your own opinion", Society must be radically changed (1), Society must be gradually improved by reforms (2) and Society must be valiantly defended (3). As a measure for obedience we consider the questions on the virtues that children should be encouraged to learn at home ${ }^{10}$. The question assigns value 1 if the respondent believes that obedience is important and zero if she does not mention it.

\subsection{Specification}

For our within-country empirical analysis, we run a series of OLS regressions of the following type ${ }^{11}$ :

$$
Y_{i j t}=\beta_{0}+\beta_{1} \text { family_ties }{ }_{i j t}+\beta_{2} X_{i j t}+\beta_{3} \gamma_{j}+\delta_{t}+\epsilon_{i j t}
$$

where the left hand side variable $Y_{i j t}$ represents the realization of a certain variable for individual $i$ in country $j$ at time $t$, where time is given by the survey wave. Family_ties $i_{i j t}$ is our variable of interest and the value of this variable is coded as increasing with the strength of family ties. $X_{i j t}$ are our controls. Our choice of controls is standard and follows the relevant literature. In order to eliminate the impact of other country characteristics, all the regressions include country fixed effects, $\gamma_{j}$, which are likely to underestimate the effect of family ties to the extent that their impact has been absorbed in the national culture. We also include time effects, $\delta_{t}$, to take into account general trends in values over time. In spite of the inclusion of country fixed effects, we are well aware of the difficulty in interpreting the observed correlations as causal effects. Our results in this part can therefore be interpreted as mere correlations; whenever we use the word "impact" or "effect" of family ties on political attitudes it is only to simplify the exposition.

\subsection{Results}

Our results on the relationship between family ties, political participation and inward looking attitudes are reported in Tables 1 and 2. According to the political science literature ${ }^{12}$, important determinants of political behavior are demographic characteristics such as age, gender, race and especially education and income. Education appears to be the most important determinant of political interest as it is the best proxy for both information and civic virtues. The effect of age can be ambiguous, on the one hand young people should be more militant, on the other hand, life experience should increase one's information

\footnotetext{
${ }^{10}$ Tabellini (2009) uses this question in a similar vein.

${ }^{11}$ We test the robustness of our results using ordered logit and nothing changes.

12 See Wolfinger and Rosestone (1980) for a survey.
} 
and retired people may have more time in their hands. According to the literature, marital status should not be such an important determinant of interest in politics. Higher income households should be more interested in politics. Interest in politics and political action should be more diffused among men.

The results reported in Table 1 are broadly in line with previous findings. In our sample, interest in politics grows with income and education ${ }^{13}$. Men are always more interested in politics and more active in political activity. The relationship between interest in politics and age is u-shaped. Employed people are more likely to discuss politics than people out of the labor force (the excluded group) and the unemployed. There is no difference for many measures of political action between employed and the unemployed, on the other hand unemployed people are more likely to participate in the occupation of buildings, as expected. Married and single people are more interested and tend to discuss more about political matters than divorced people. On the other hand married people are more reluctant to participate in political activism, contrary to singles who are especially more likely to attend demonstrations. The most likely interpretation is that singles have more time since they (generally) have no children, and they may be more left leaning. ${ }^{14}$

Our variable on the strength of family ties is always significant with the expected sign even after controlling for country and year fixed effects and the whole range of individual controls. Individuals with strong family ties are consistently less interested in politics and also less likely to participate to any form of political activity from discussing politics to provide voluntary work for a political party to the most active forms of political participation, such as strikes, demonstrations or signing a petition. The magnitude of the coefficients is not negligible: moving from the lowest 5 th percentile to the highest 5 th percentile of the strength of family ties is equivalent to the impact of belonging to the highest income group of the income distribution and slightly smaller than the effect of having only primary education relative to the highest level of education. The impact is therefore substantial as income and education are the most important determinants of political participation.

Table 2 shows results on inward looking attitudes. In particular, we show evidence of a negative correlation between family ties and trust, but a positive correlation between family ties and trust in the family. This negative association between trusting the family and generalized trust, a critical component of social capital has been the core of the amoral familism hypothesis of Banfield (1958). That is the amoral familist equilibrium is an extreme version of a situation in which trust for family members is absolute and mistrust of everybody else just as strong. The impact of family ties on trust is also substantial, moving from the lowest 5th percentile to the highest 5th percentile of the strength of family ties is equivalent to almost double the effect of the impact of having only primary education and of belonging to the highest level of the income distribution.

\footnotetext{
${ }^{13}$ The effect of education is consistent with the analysis of Glaeser, Ponzetto and Shleifer (2007) on the role of education in sustaining democratic institutions and political participation.

${ }^{14}$ Also political activism related to gay group activities would be primarily performed by singles.
} 
We finally look at two other variables which should help to perpetuate amoral familism across generations: these variables are obedience as one of the most important values that should be transmitted to children and the reluctance to change the society. Results are consistent with our prior: individuals with strong family ties also think that children should be obedient and that society should be valiantly defended and not radically changed. Given the emphasis on obedience strong family ties tend to persist ${ }^{15}$. The magnitude of the effect is comparable to the impact of family ties on trust.

\section{Evidence on immigrants}

We now turn to evidence drawn from immigrants. As discussed in the introduction, several papers have used this approach to help establish causality and to test whether cultural traits travel with people. That is, if immigrants behave in their new country of residence as at home this shows two things. First, the effect of family ties is not an artifact of differences across countries in institutions, policies etc. Even though in the cross country evidence presented above we always included country fixed effects it is still worth checking that family ties matter when individuals coming from differenct countries of origin face the same institutional and economic environment. Second, immigrants behave in their new country of residence as at home; this shows that family ties stick to people when they move. Obviously cultural assimilation does take place and an important avenue for future research is to examine the speed of $i^{16}$. The literature reviewed in the introduction generally looks at immigrants in the US ${ }^{17}$. Here we consider immigrants in 32 destination countries, so our results cannot be driven by some special features of a particular receiving country (the US). Our sample consists of second generation immigrants, i.e. individuals born in a given country and whose father was born abroad. We associate to each immigrant the measure of family ties constructed from the World Value Survey, i.e. we associate to each immigrant living in one of the 32 countries of the survey the average level of family ties of his/her country of origin.

\subsection{Dependent variables}

\subsubsection{Political attitudes}

We select similar types of questions on political interest, political action and inward looking attitudes, however due to data availability the variables are in some cases not the same. As measures of political attitudes we select the following questions. Three measures of time spent per week watching TV, reading

\footnotetext{
${ }^{15}$ Tabellini (2009) shows, using the same answer for the WWS, that reliance on obedience is a component of cultural traits associated with lower level of development in European regions.

${ }^{16}$ For interesting empirical work on persistence of cultural traits see Guiso Sapienza and Zingales (2009), and Tabellini (2008) for a model of cultural transmission of trust.

${ }^{17}$ Exceptions are Alesina and Giuliano (2007 and 2009) and Luttmer and Singhal (2008) who also use evidence from the European Social Survey.
} 
newspapers or listening to radio programmes about politics and current affairs. The questions are as follows: "On a average weekday, how much of your time watching television is spent watching news or programmes about politics and current affairs", "On an average weekday, how much of your time listening to the radio is spent listening to news or programmes about politics and current affairs?", "On an average weekday, how much of your time is spent reading newspapers about politics and current affairs?"; the answer to the three questions is coded in the following way: No time at all (0), Less than 0.5 hour (1), 0.5 hour to 1 hour (2), More than 1 hour, up to 1.5 hours (3), More than 1.5 hours, up to 2 hours (4), More than 2 hours, up to 2.5 hours (5), More than 2.5 hours, up to 3 hours (6), More than 3 hours (7). The fourth measure asks the respondent "How interested are you in politics", and the answer can take three values: Very interested (3), Quite interested (2) and Hardly interested (1).

We also select three questions of political action similar to the ones of the World Value Survey. The questions are: "During the last 12 months, have you done any of the following?" Signed a petition, taken part in a lawful public demonstration and boycotted certain products?", and the answer is simply yes or no. As in the World Value survey, there are three different questions for each type of political activity. Note that this question is somehow different than the World Value Survey, where the respondent was asked if he/she ever did any of this action or if he/she could contemplate doing it. The answer to the European Social Survey is much more demanding as it asks the respondent about the actual action in the last 12 months.

\subsubsection{Inward looking attitudes}

As a measure of inward looking attitudes we chose the following questions: a standard measure on generalized trust "Using this card, generally speaking, would you say that most people can be trusted, or that you can't be too careful in dealing with people? Please tell me on a score of 0 to 10, where 0 means you can't be too careful and 10 means that most people can be trusted". The European Social Survey does not have any question on obedience as an important value to be transmitted to children, therefore we choose a question that should pick up more or less obedience and reluctance to change. We select the following question: "Now I will briefly describe some people. Please listen to each description and tell me how much each person is or is not like you. She/he believes that people should do what they are told. She/he thinks people should follow rules at all times, even when no-one is watching", the answer could be Very much like me (6), Like me (5) and Somewhat like me (4), A little like me (3), Not like me (2), Not like me at all (1).

\subsection{Specification}

For consistency with the regressions of the previous section, we run the following model in OLS regressions ${ }^{18}$ :

${ }^{18}$ As before, we also run ordered logit and our results do not change. 


$$
Y_{i k c}=\alpha_{0}+\alpha_{1} \text { family_ties }_{k}+\alpha_{2} X_{i}+\delta_{c}+\varepsilon_{i k c}
$$

where $Y_{i k c}$ is the left hand side of interest for individual $i$, living in country $c$ and whose father comes from country $k . X_{i}$ are individual controls, family_ties $s_{k}$ is our measure of the strength of family ties which varies by immigrant's country of origin and $\delta_{c}$ is a full set of country of residence dummies. Standard errors are clustered at the country of origin level.

\subsection{Results}

In Table 3, we test for the effects of family ties on political interest, political action and inward looking attitudes among immigrants. We find a strong effect of family ties on almost all variables of interest. Immigrants coming from countries with strong family ties tend to follow less political events (the coefficients on following politics on TV, the radio or the newspapers is always negative and significant with the exception of watching political news on TV) and are generally less interested in politics.

The results for political activism are a bit weaker than the within country analysis. One possibility, as mentioned above, is that the definition of political activism is much more strict in the ESS compared to the WVS as it asks respondents whether they were involved in these forms of political action in the last 12 months. Also immigrants can be a bit more reluctant to be involved in this type of political action in a foreign country as this could have some effects on the residence status of their families.

We find a very strong result on the impact of family ties on generalized level of trust. Together with the work of Todd (1985) this result highlights the importance of the family in determining individuals' ideology and social values and attitudes. Finally, strong family ties immigrants tend to follow rules more strictly than immigrants coming from weak family ties countries. The results on immigrants are similar in magnitude to the results on the within country analysis: moving from the lowest 5 th percentile to the highest 5 th percentile of the strength of family ties has the same effect of having primary education. The results on trust are particularly telling as in this case the impact of moving from the lowest 5 th percentile to the highest 5th percentile of the strength of family ties is almost three times as large as the impact of having only primary education relative to the excluded group of higher education.

The other variables affect political participation and inward looking attitudes in the expected direction. Higher income households are more interested in politics (with the exception of listening to political programs on the radio for which income has a negative effect), similarly for individuals with a higher level of education. Higher income households also tend to trust more and follow rules less; education has the same effect. As before, men tend to be more interested in politics (although in the ESS they are less likely to sign a petition), trust more and follow rule less. As before and consistently with the literature on 
political participation, marital status is not a relevant determinant of political participation.

\section{Conclusions}

Strong family ties are associated with, and possibly "cause", lack of generalized trust. In addition, individuals with strong family ties do not engage much in political activity, and are less interested in public policies, the common good and the polity in general. An extreme version of strong family ties is the "amoral familism" which, according to Banfield (1958) was a major determinant of underdevelopment. The strength of family ties could then reduce social capital and as a result have an important effect on economic development.

We have established these results with two sets of regressions. One involving within country comparisons of individuals using data drawn from the World Value Survey. It is worth stressing again that we always include fixed effects in our regressions, so our results do not depend on comparing, say, the average Swede with the average Italian. Second, considering the behavior of immigrants who have moved in 32 different destination countries. We confirm the relationship between family ties, trust and political participation even amongst immigrants and independently of the destination country.

\section{References}

[1] Alesina, A. and P. Giuliano (2007), "The Power of the Family," NBER Working Paper 13051.

[2] Alesina A. and P. Giuliano (2009) "Preferences for redistribution" NBER working paper, forthcoming in A. Bisin and J. Benhabib (eds.) Handbook of Social Economics North Holland, Amsterdam.

[3] Alesina A. and N. Fuchs-Schundeln (2007) "Good Bye Lenin (or not?). The effect of Communism on people's preferences" American Economic Review, 907-28.

[4] Alesina A. E. Glaeser and B. Sacerdote (2005) "Work and Leisure in the US and Europe: Why so Different?" Brookings Papers on Economic Activity, Fall

[5] Alesina A. and E. La Ferrara (2005) " Preference for Redistribution in the Land of Opportunity" Journal of Public Economics, 89 897-931

[6] Alesina A. and E. La Ferrara (2002), "Who Trust Others?" Journal of Public Economics 85, 207-34.

[7] Banfield, E. C. (1958), The Moral Basis of a Backward Society, New York: The Free Press 
[8] Bentolilla, S. and A. Ichino, "Unemployment and Consumption Near and Far Away From the Mediterranean?" Journal of Population Economics, forthcoming.

[9] Bertrand, M. and A. Schoar (2006), "The Role of Family in Family Firms", Journal of Economic Perspectives, Spring 2006

[10] Bisin, A. and T. Verdier (2001), "The Economics of Cultural Transmission and the Evolution of Preferences", Journal of Economic Theory, 97(2), 298-319

[11] Esping-Andersen (1999), Social Foundation of Post-Industrial Economies, Oxford, Oxford University Press, 1999

[12] Fernandez R and A. Fogli (2005), "Culture: An Empirical Investigation of Beliefs, Work and Fertility", American Economic Association Journals, Macroeconomics, January

[13] Fukuyama, F. (1995) Trust: The Social Virtues and the Creation of Prosperity, New York: Free Press

[14] Gambetta, A. (1990), The Sicilian Mafia, Oxford University Press, Oxford UK

[15] Giuliano, P. (2007), "Living Arrangements in Western Europe: Does Cultural Origin Matter?", Journal of the European Economic Association, 5(5): 927-952.

[16] Guiso, L., P. Sapienza and L. Zingales (2004), "Cultural Biases in Economic Exchange", NBER Working Paper 11005

[17] Guiso, L., P. Sapienza and L. Zingales (2006), "Does Culture Affect Economic Outcomes?" Journal of Economic Perspectives, Spring 2006

[18] Inglehart, R. and W. Baker (2000), "Modernization, Cultural Change and the Persistent of Traditional Values", American Sociological Review, 65: $19-51$

[19] Merlo, A. (2006), "Whither Political Economy? Theories, Facts and Issues", Blundell, R., W. newey and T. Persson (eds.), Advances in Economics and Econometrics, Theory and Applications, Ninth World Congress of the Econometric Society, Vol. I, pp. 381-421, Cambridge, Cambridge University Press

[20] Orizo, F. (1996), Sistemas de valores en la Espana de los 90, Madrid, CIS

[21] Putnam, R. (1993), Making Democracy Work. Civic Traditions in Modern Italy, Princeton-NJ: Princeton University Press.

[22] Putnam, R. (2000), Bowling Alone, New York: Simon \& Schuster 
[23] Reher, D., (1998) "Family Ties in Western Europe: Persistent Contrasts", Population and Development Review, XXIV 203-234

[24] Tabellini G. (2008), "The Scope of Cooperation: Values and Incentives, Quarterly Journal of Economics, August 2008

[25] Tabellini, "Culture and Institutions: Economic Development in the Regions of Europe", Journal of the European Economic Association, forthcoming

[26] Todd E. (1985) The explanation o Ideology Basil Blackwell, New York

[27] Wolfinger and Rosenstone (1980), Who votes, New Haven, Yale University Press 
Figure 1

Family Ties
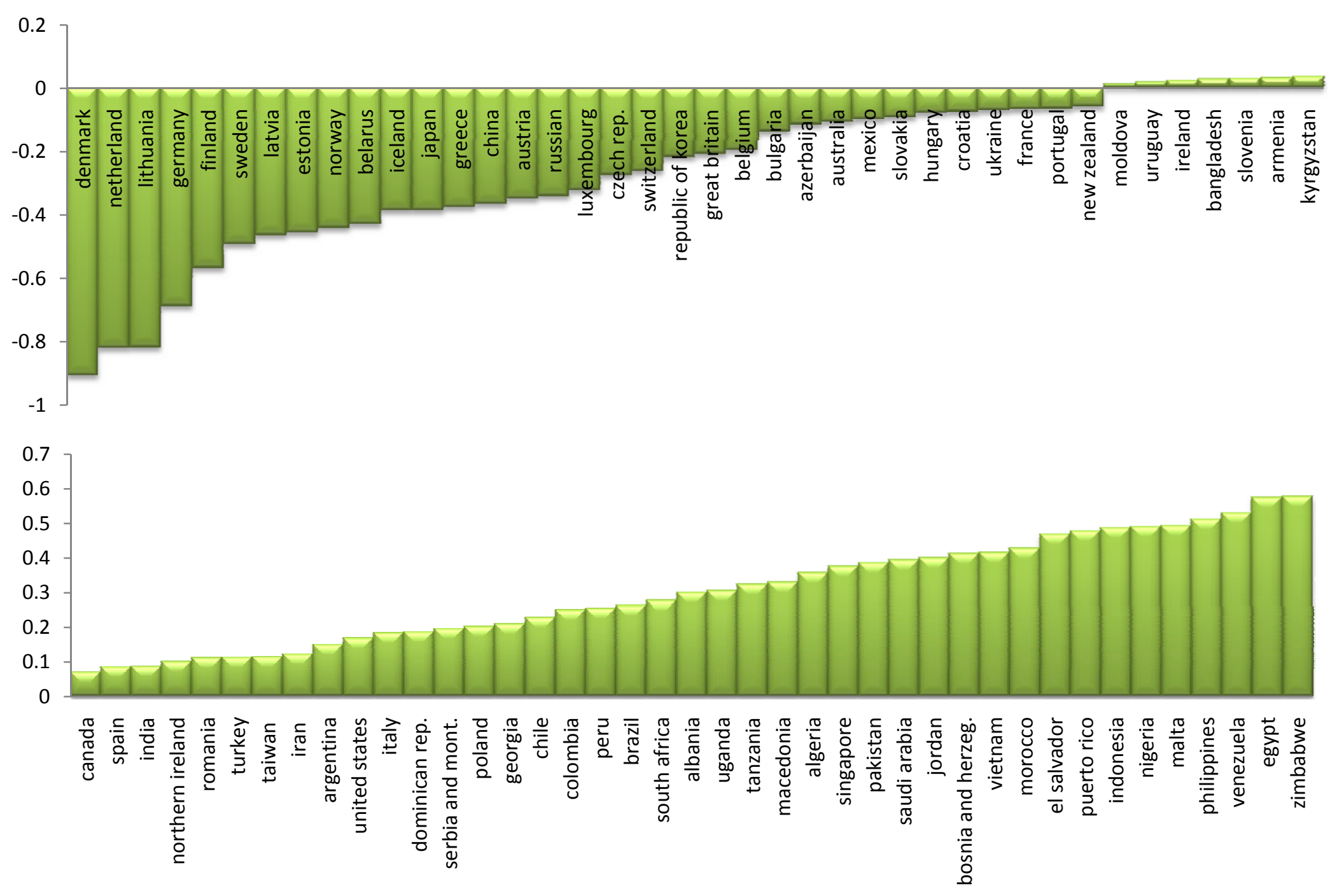
Table 1

Family Ties and Political Participation

\begin{tabular}{|c|c|c|c|c|c|c|c|c|}
\hline & $\begin{array}{c}\text { (1) } \\
\text { Discuss political } \\
\text { matters }\end{array}$ & $\begin{array}{c}\text { (2) } \\
\text { Unpaid work } \\
\text { in political parties }\end{array}$ & $\begin{array}{c}(3) \\
\text { Interest } \\
\text { in politics }\end{array}$ & $\begin{array}{c}\text { (4) } \\
\text { Sign } \\
\text { petition }\end{array}$ & $\begin{array}{l}\text { (5) } \\
\text { Joining in } \\
\text { boycotts }\end{array}$ & $\begin{array}{c}\text { (6) } \\
\text { Attending } \\
\text { demonstrations }\end{array}$ & $\begin{array}{c}(7) \\
\text { Joining } \\
\text { strikes }\end{array}$ & $\begin{array}{c}(8) \\
\text { Occupying } \\
\text { buildings }\end{array}$ \\
\hline \multirow[t]{2}{*}{ Family ties } & -0.010 & -0.001 & -0.013 & -0.029 & -0.051 & -0.034 & -0.040 & -0.026 \\
\hline & $(0.002)^{* * *}$ & $(0.001)^{* *}$ & $(0.002) * * *$ & $(0.002) * * *$ & $(0.002)^{* * *}$ & $(0.002) * * *$ & $(0.002)^{* * *}$ & $(0.001)^{* * *}$ \\
\hline \multirow[t]{2}{*}{ Male } & 0.182 & 0.027 & 0.184 & 0.079 & 0.117 & 0.144 & 0.098 & 0.060 \\
\hline & $(0.004)^{* * *}$ & $(0.002)^{* * *}$ & $(0.005) * * *$ & $(0.004)^{* * *}$ & $(0.004)^{* * *}$ & $(0.004) * * *$ & $(0.004)^{* * *}$ & $(0.003) * * *$ \\
\hline \multirow[t]{2}{*}{ Primary } & -0.234 & -0.018 & -0.160 & -0.210 & -0.155 & -0.219 & -0.079 & -0.035 \\
\hline & $(0.006)^{* * *}$ & $(0.003)^{* * *}$ & $(0.008) * * *$ & $(0.007)^{* * *}$ & $(0.007)^{* * *}$ & $(0.007)^{* * *}$ & $(0.006)^{* * *}$ & $(0.004) * * *$ \\
\hline \multirow[t]{2}{*}{ Secondary } & -0.107 & -0.013 & -0.100 & -0.103 & -0.111 & -0.151 & -0.075 & -0.034 \\
\hline & $(0.005)^{* * *}$ & $(0.003)^{* * *}$ & $(0.006) * * *$ & $(0.006)^{* * *}$ & $(0.006)^{* * *}$ & $(0.006) * * *$ & $(0.005)^{* * *}$ & $(0.004) * * *$ \\
\hline \multirow[t]{2}{*}{ Age } & 0.196 & 0.019 & 0.123 & 0.131 & 0.099 & 0.122 & 0.044 & 0.011 \\
\hline & $(0.007)^{* * *}$ & $(0.003)^{* * *}$ & $(0.009)^{* * *}$ & $(0.009)^{* * *}$ & $(0.007)^{* * *}$ & $(0.008)^{* * *}$ & $(0.006)^{* * *}$ & $(0.005)^{* *}$ \\
\hline \multirow[t]{2}{*}{ Age squared } & -0.018 & -0.001 & -0.008 & -0.016 & -0.014 & -0.016 & -0.008 & -0.004 \\
\hline & $(0.001)^{* * *}$ & $(0.000)^{* * *}$ & $(0.001)^{* * *}$ & $(0.001)^{* * *}$ & $(0.001)^{* * *}$ & $(0.001)^{* * *}$ & $(0.001)^{* * *}$ & $(0.001) * * *$ \\
\hline \multirow[t]{2}{*}{ Employed } & 0.029 & 0.011 & -0.013 & 0.052 & 0.046 & 0.061 & 0.034 & 0.007 \\
\hline & $(0.006)^{* * *}$ & $(0.002)^{* * *}$ & $(0.007) *$ & $(0.006)^{* * *}$ & $(0.006) * * *$ & $(0.006)^{* * *}$ & $(0.005)^{* * *}$ & $(0.004) * *$ \\
\hline \multirow{2}{*}{ Unemployed } & 0.005 & 0.018 & -0.004 & 0.011 & 0.042 & 0.049 & 0.048 & 0.021 \\
\hline & $(0.009)$ & $(0.004)^{* * *}$ & $(0.012)$ & $(0.011)$ & $(0.009)^{* * *}$ & $(0.010)^{* * *}$ & $(0.008)^{* * *}$ & $(0.006)^{* * *}$ \\
\hline \multirow[t]{2}{*}{ Married } & 0.025 & 0.003 & 0.013 & 0.001 & -0.013 & -0.004 & -0.020 & -0.014 \\
\hline & $(0.006)^{* * *}$ & $(0.002)$ & $(0.008) *$ & $(0.007)$ & $(0.006)^{* *}$ & $(0.007)$ & $(0.005)^{* * *}$ & $(0.004)^{* * *}$ \\
\hline \multirow[t]{2}{*}{ Single } & 0.022 & 0.002 & 0.022 & -0.001 & 0.011 & 0.030 & 0.003 & 0.006 \\
\hline & $(0.008)^{* * *}$ & $(0.003)$ & $(0.010)^{* *}$ & $(0.009)$ & $(0.008)$ & $(0.009)^{* * *}$ & $(0.007)$ & $(0.005)$ \\
\hline \multirow[t]{2}{*}{ Medium income } & 0.050 & -0.001 & 0.012 & 0.069 & 0.039 & 0.041 & 0.014 & -0.001 \\
\hline & $(0.004)^{* * *}$ & $(0.002)$ & $(0.006)^{* *}$ & $(0.005)^{* * *}$ & $(0.005)^{* * *}$ & $(0.005)^{* * *}$ & $(0.004)^{* * *}$ & $(0.003)$ \\
\hline \multirow[t]{2}{*}{ Higher income } & 0.102 & 0.000 & 0.060 & 0.128 & 0.064 & 0.077 & 0.027 & -0.004 \\
\hline & $(0.005)^{* * *}$ & $(0.002)$ & $(0.006)^{* * *}$ & $(0.006)^{* * *}$ & $(0.005)^{* * *}$ & $(0.006)^{* * *}$ & $(0.005)^{* * *}$ & $(0.003)$ \\
\hline Observations & 127347 & 69756 & 95699 & 116389 & 113044 & 117398 & 113269 & 112249 \\
\hline R-squared & 0.12 & 0.07 & 0.09 & 0.27 & 0.17 & 0.13 & 0.10 & 0.08 \\
\hline
\end{tabular}


Table 2

Family Ties, Trust and Inward Looking Attitudes

\begin{tabular}{|c|c|c|c|c|}
\hline & $\begin{array}{c}(1) \\
\text { Generalized Trust }\end{array}$ & $\begin{array}{c}\text { (2) } \\
\text { Trust the Family }\end{array}$ & $\begin{array}{c}\text { (3) } \\
\text { Child Qualities: } \\
\text { Obedience }\end{array}$ & $\begin{array}{c}\text { (4) } \\
\text { Basic Kinds of } \\
\text { Attitudes } \\
\text { Concerning Society }\end{array}$ \\
\hline \multirow[t]{2}{*}{ Family ties } & -0.007 & 0.072 & 0.025 & 0.016 \\
\hline & $(0.001)^{* * *}$ & $(0.004) * * *$ & $(0.001)^{* * *}$ & $(0.002) * * *$ \\
\hline \multirow[t]{2}{*}{ Male } & 0.014 & 0.019 & -0.005 & -0.033 \\
\hline & $(0.003)^{* * *}$ & $(0.008) * *$ & $(0.003)$ & $(0.004)^{* * *}$ \\
\hline \multirow[t]{2}{*}{ Primary } & -0.050 & -0.083 & 0.068 & 0.044 \\
\hline & $(0.004) * * *$ & $(0.029) * * *$ & $(0.005)^{* * *}$ & $(0.006) * * *$ \\
\hline \multirow[t]{2}{*}{ Secondary } & -0.039 & -0.068 & 0.032 & 0.025 \\
\hline & $(0.004)^{* * *}$ & $(0.021)^{* * *}$ & $(0.004)^{* * *}$ & $(0.005)^{* * *}$ \\
\hline \multirow[t]{2}{*}{ Age } & 0.037 & -0.023 & -0.053 & -0.024 \\
\hline & $(0.005) * * *$ & $(0.015)$ & $(0.006)^{* * *}$ & $(0.007)^{* * *}$ \\
\hline \multirow[t]{2}{*}{ Age squared } & -0.003 & 0.004 & 0.006 & 0.004 \\
\hline & $(0.001)^{* * *}$ & $(0.002)^{* *}$ & $(0.001) * * *$ & $(0.001)^{* * *}$ \\
\hline \multirow[t]{2}{*}{ Employed } & 0.023 & 0.019 & -0.020 & -0.005 \\
\hline & $(0.004) * * *$ & $(0.011)^{*}$ & $(0.004)^{* * *}$ & $(0.005)$ \\
\hline \multirow[t]{2}{*}{ Unemployed } & -0.002 & -0.052 & -0.005 & -0.007 \\
\hline & $(0.006)$ & $(0.024)^{* *}$ & $(0.007)$ & $(0.009)$ \\
\hline \multirow[t]{2}{*}{ Married } & 0.010 & 0.131 & 0.012 & 0.007 \\
\hline & $(0.004)^{* *}$ & $(0.015)^{* * *}$ & $(0.004) * * *$ & $(0.005)$ \\
\hline \multirow[t]{2}{*}{ Single } & 0.021 & 0.070 & -0.004 & 0.001 \\
\hline & $(0.005) * * *$ & $(0.019) * * *$ & $(0.006)$ & $(0.007)$ \\
\hline \multirow[t]{2}{*}{ Medium income } & 0.016 & 0.052 & -0.023 & 0.003 \\
\hline & $(0.003) * * *$ & $(0.010)^{* * *}$ & $(0.003)^{* * *}$ & $(0.004)$ \\
\hline \multirow[t]{2}{*}{ High income } & 0.041 & 0.071 & -0.054 & -0.009 \\
\hline & $(0.004)^{* * *}$ & $(0.011)^{* * *}$ & $(0.004) * * *$ & $(0.005)^{*}$ \\
\hline Observations & 119435 & 30602 & 123035 & 98040 \\
\hline R-squared & 0.10 & 0.19 & 0.12 & 0.05 \\
\hline
\end{tabular}

Notes: [1] Each regression controls for country and wave fixed effects; [2] Robust standard errors in parenthesis, *** significant at $1 \%$, ** significant at $5 \%$, * significant at $10 \%$. 
Table 3

Family Ties, Political Participation and Inward Looking Attitudes

Evidence from Immigrants in 32 Destination Countries

\begin{tabular}{|c|c|c|c|c|c|c|c|c|c|}
\hline & $\begin{array}{c}(1) \\
\text { TV } \\
\text { politics }\end{array}$ & $\begin{array}{c}\text { (2) } \\
\text { Radio } \\
\text { politics }\end{array}$ & $\begin{array}{c}\text { (3) } \\
\text { Newspaper } \\
\text { politics }\end{array}$ & $\begin{array}{l}(4) \\
\text { Interested } \\
\text { in politics }\end{array}$ & $\begin{array}{c}\text { (5) } \\
\text { Signed } \\
\text { petition }\end{array}$ & $\begin{array}{l}(6) \\
\text { Boycotted } \\
\text { products }\end{array}$ & $\begin{array}{c}(7) \\
\text { Lawful } \\
\text { demons. }\end{array}$ & $\begin{array}{c}(8) \\
\text { Trust }\end{array}$ & $\begin{array}{c}(9) \\
\text { Follow } \\
\text { rules }\end{array}$ \\
\hline \multirow{4}{*}{$\begin{array}{l}\text { Family ties in the country } \\
\text { of origin } \\
\text { Age }\end{array}$} & -0.027 & -0.113 & -0.091 & -0.111 & 0.010 & -0.030 & 0.033 & -0.458 & 0.119 \\
\hline & $(0.043)$ & $(0.063)^{*}$ & $(0.039)^{* *}$ & $(0.053) * *$ & $(0.025)$ & $(0.018)^{*}$ & $(0.020)$ & $(0.098) * * *$ & $(0.065)^{*}$ \\
\hline & 0.027 & 0.033 & 0.002 & 0.022 & 0.007 & 0.011 & 0.003 & -0.016 & -0.015 \\
\hline & $(0.005) * * *$ & $(0.007) * * *$ & $(0.005)$ & $(0.006)^{* * *}$ & $(0.002) * * *$ & $(0.002)^{* * *}$ & $(0.002)$ & $(0.014)$ & $(0.008)^{* *}$ \\
\hline \multirow[t]{2}{*}{ Age squared } & -0.000 & -0.000 & 0.000 & -0.000 & -0.000 & -0.000 & -0.000 & 0.000 & 0.000 \\
\hline & $(0.000)^{*}$ & $(0.000) * * *$ & $(0.000)^{*}$ & $(0.000)^{* *}$ & $(0.000) * * *$ & $(0.000)^{* * *}$ & $(0.000)$ & $(0.000)$ & $(0.000)^{* * *}$ \\
\hline \multirow[t]{2}{*}{ Male } & 0.209 & 0.073 & 0.173 & 0.273 & -0.038 & -0.002 & -0.002 & 0.167 & 0.038 \\
\hline & $(0.042) * * *$ & $(0.046)$ & $(0.027) * * *$ & $(0.029) * * *$ & $(0.010) * * *$ & $(0.012)$ & $(0.010)$ & $(0.078)^{* *}$ & $(0.042)$ \\
\hline \multirow[t]{2}{*}{ Married } & 0.061 & 0.055 & -0.050 & -0.054 & -0.015 & -0.023 & -0.013 & -0.127 & 0.158 \\
\hline & $(0.037)$ & $(0.071)$ & $(0.048)$ & $(0.033)$ & $(0.013)$ & $(0.012)^{*}$ & $(0.010)$ & $(0.081)$ & $(0.054)^{* * *}$ \\
\hline \multirow[t]{2}{*}{ Single } & 0.071 & -0.002 & -0.032 & 0.027 & 0.052 & 0.055 & 0.039 & -0.103 & -0.103 \\
\hline & $(0.061)$ & $(0.079)$ & $(0.063)$ & $(0.048)$ & $(0.014) * * *$ & $(0.012)^{* * *}$ & $(0.020)^{*}$ & $(0.145)$ & $(0.075)$ \\
\hline \multirow[t]{2}{*}{ Primary } & -0.199 & -0.209 & -0.417 & -0.635 & -0.181 & -0.136 & -0.067 & -1.057 & 0.257 \\
\hline & $(0.074)^{* *}$ & $(0.119)^{*}$ & $(0.052) * * *$ & $(0.067)^{* * *}$ & $(0.035) * * *$ & $(0.028)^{* * *}$ & $(0.017) * * *$ & $(0.105)^{* * *}$ & $(0.077)^{* * *}$ \\
\hline \multirow[t]{2}{*}{ Secondary } & -0.112 & -0.106 & -0.225 & -0.290 & -0.093 & -0.109 & -0.025 & -0.704 & 0.240 \\
\hline & $(0.045)^{* *}$ & $(0.034) * * *$ & $(0.017) * * *$ & $(0.023) * * *$ & $(0.022) * * *$ & $(0.024)^{* * *}$ & $(0.015)^{*}$ & $(0.082)^{* * *}$ & $(0.050)^{* * *}$ \\
\hline \multirow[t]{2}{*}{ Unemployed } & 0.030 & -0.425 & 0.082 & -0.054 & -0.040 & -0.008 & 0.018 & -0.507 & -0.138 \\
\hline & $(0.065)$ & $(0.063) * * *$ & $(0.067)$ & $(0.032)^{*}$ & $(0.023)^{*}$ & $(0.029)$ & $(0.022)$ & $(0.154) * * *$ & $(0.096)$ \\
\hline \multirow[t]{2}{*}{ Out of lab. force } & 0.078 & 0.019 & 0.078 & 0.030 & -0.003 & 0.031 & -0.007 & -0.018 & -0.034 \\
\hline & $(0.042)^{*}$ & $(0.049)$ & $(0.030)^{* *}$ & $(0.031)$ & $(0.013)$ & $(0.012)^{* *}$ & $(0.017)$ & $(0.058)$ & $(0.049)$ \\
\hline \multirow[t]{2}{*}{ Family income } & -0.013 & -0.042 & 0.030 & 0.053 & 0.006 & 0.003 & 0.001 & 0.067 & -0.023 \\
\hline & $(0.011)$ & $(0.014) * * *$ & $(0.009) * * *$ & $(0.007) * * *$ & $(0.003) * *$ & $(0.003)$ & $(0.002)$ & $(0.018) * * *$ & $(0.012)^{*}$ \\
\hline Observations & 4451 & 3513 & 3438 & 4652 & 4635 & 4635 & 4654 & 4652 & 4499 \\
\hline R-squared & 0.11 & 0.07 & 0.11 & 0.17 & 0.14 & 0.12 & 0.05 & 0.13 & 0.12 \\
\hline
\end{tabular}

Notes: [1] Each regression controls for country of destination fixed effects; [2] Standard errors are clustered at the country of origin level, $* * *$ significant at $1 \%$, ** significant at $5 \%, *$ significant at $10 \%$; 


\section{Data Appendix}

Table 4

World Value Survey, List of Countries, by Wave

\begin{tabular}{|c|c|c|c|}
\hline $\begin{array}{l}\text { First Wave } \\
1981-1984\end{array}$ & $\begin{array}{l}\text { Second Wave } \\
1989-1993\end{array}$ & $\begin{array}{l}\text { Third Wave } \\
\text { 1994-1999 }\end{array}$ & $\begin{array}{l}\text { Fourth Wave } \\
1999-2004\end{array}$ \\
\hline Argentina & Argentina & Albania & Albania \\
\hline Australia & Austria & Azerbaijan & Algeria \\
\hline Belgium & Belgium & Argentina & Argentina \\
\hline Canada & Brazil & Australia & Austria \\
\hline Denmark & Bulgaria & Bangladesh & Bangladesh \\
\hline France & Belarus & Armenia & Belgium \\
\hline Hungary & Canada & Bosnia and Herzegovina & Bosnia and Herzegovina \\
\hline Iceland & Chile & Brazil & Bulgaria \\
\hline Ireland & China & Bulgaria & Belarus \\
\hline Italy & Czech Republic & Belarus & Canada \\
\hline Japan & Denmark & Chile & Chile \\
\hline Republic of Korea & Estonia & China & China \\
\hline Malta & Finland & Taiwan & Croatia \\
\hline Netherlands & France & Colombia & Czech Republic \\
\hline Norway & Germany & Croatia & Denmark \\
\hline Spain & Hungary & Czech Republic & Estonia \\
\hline Sweden & Iceland & Dominican Republic & Finland \\
\hline Great Britain & India & El Salvador & France \\
\hline United states & Ireland & Estonia & Germany \\
\hline West Germany & Italy & Finland & Greece \\
\hline \multirow[t]{20}{*}{ Northern Ireland } & Japan & Georgia & Hungary \\
\hline & Republic of Korea & Germany & Iceland \\
\hline & Latvia & Hungary & India \\
\hline & Lithuania & India & Indonesia \\
\hline & Malta & Japan & Iran \\
\hline & Mexico & Republic of Korea & Iraq \\
\hline & Netherlands & Latvia & Ireland \\
\hline & Nigeria & Lithuania & Israel \\
\hline & Norway & Mexico & Italy \\
\hline & Poland & Moldova & Japan \\
\hline & Portugal & New Zealand & Jordan \\
\hline & Romania & Nigeria & Republic of Korea \\
\hline & Russian Fed. & Norway & Kyrgyzstan \\
\hline & Slovakia & Pakistan & Latvia \\
\hline & Slovenia & Peru & Lithuania \\
\hline & South Africa & Philippines & Luxembourg \\
\hline & Spain & Poland & Malta \\
\hline & Sweden & Puerto Rico & Mexico \\
\hline & Switzerland & Romania & Moldova \\
\hline & Turkey & Russian Federation & Morocco \\
\hline
\end{tabular}




\begin{tabular}{lll}
\hline Great Britain & Slovakia & Netherlands \\
United States & Slovenia & Nigeria \\
Northern Ireland & South Africa & Pakistan \\
& Spain & Peru \\
& Sweden & Philippines \\
& Switzerland & Poland \\
& Turkey & Portugal \\
& Ukraine & Puerto Rico \\
& Macedonia & Romania \\
& Great Britain & Russian Federation \\
& United states & Saudi Arabia \\
& Uruguay & Singapore \\
& Venezuela & Slovakia \\
& Serbia and Montenegro & Vietnam \\
& Slovenia \\
& South Africa \\
& Zimbabwe \\
& Spain \\
& Sweden \\
& Turkey \\
& Uganda \\
& Ukraine \\
& Macedonia \\
& Egypt \\
& Great Britain \\
& Thited States \\
& Serbia and Montenegro \\
& Northern Ireland \\
\hline &
\end{tabular}


Table 5

European Social Survey, List of Countries, by Wave

\begin{tabular}{|c|c|c|c|}
\hline & ESS round1 & ESS round2 & ESS round3 \\
\hline 1 & Austria & Austria & Austria \\
\hline 2 & Belgium & Belgium & Belgium \\
\hline 3 & & & Bulgaria \\
\hline 4 & Switzerland & Switzerland & Switzerland \\
\hline 5 & Czech Republic & Czech Republic & \\
\hline 6 & & & Cyprus \\
\hline 7 & Germany & Germany & Germany \\
\hline 8 & Denmark & Denmark & Denmark \\
\hline 9 & & Estonia & Estonia \\
\hline 10 & Spain & Spain & Spain \\
\hline 11 & Finland & Finland & Finland \\
\hline 12 & France & France & France \\
\hline 13 & Great Britain & Great Britain & Great Britain \\
\hline 14 & Greece & Greece & \\
\hline 15 & Hungary & Hungary & Hungary \\
\hline 16 & Ireland & Ireland & Ireland \\
\hline 17 & Israel & & \\
\hline 18 & & Iceland & \\
\hline 19 & & & Latvia \\
\hline 20 & Italy & Italy & \\
\hline 21 & Luxembourg & Luxembourg & \\
\hline 22 & Netherland & Netherlands & Netherlands \\
\hline 23 & Norway & Norway & Norway \\
\hline 24 & Poland & Poland & Poland \\
\hline 25 & Portugal & Portugal & Portugal \\
\hline 26 & & & Romania \\
\hline 27 & & & Russia \\
\hline 28 & Sweden & Sweden & Sweden \\
\hline 29 & Slovenia & Slovenia & Slovenia \\
\hline 30 & & Slovakia & Slovakia \\
\hline 31 & & Turkey & \\
\hline 32 & & Ukraine & Ukraine \\
\hline
\end{tabular}


Table 6

World Value Survey: Summary Statistics

\begin{tabular}{lcccc}
\hline \hline Variable & Mean & S.D. & Min & Max \\
\hline Parents responsibilities & 1.776 & 0.417 & 1 & 2 \\
Respect and love for parents & 1.802 & 0.398 & 1 & 2 \\
Family important in life & 3.857 & 0.412 & 1 & 4 \\
Discuss political matters & 1.858 & 0.668 & 1 & 3 \\
Unpaid work in polit. parties & 0.035 & 0.185 & 0 & 1 \\
Interest in politics & 1.765 & 0.706 & 1 & 3 \\
Signing a petition & 2.042 & 0.809 & 1 & 3 \\
Joining in boycotts & 1.512 & 0.660 & 1 & 3 \\
Attending demonstration & 1.732 & 0.744 & 1 & 3 \\
Joining strikes & 1.299 & 0.559 & 1 & 3 \\
Occupying buildings & 1.173 & 0.433 & 1 & 3 \\
Generalized trust & 0.295 & 0.456 & 0 & 1 \\
Trust the family & 4.705 & 0.733 & 1 & 5 \\
Obedience & 0.356 & 0.478 & 0 & 1 \\
Type of society & 2.071 & 0.529 & 1 & 3 \\
Male & 0.480 & 0.500 & 0 & 1 \\
Primary & 0.253 & 0.435 & 0 & 1 \\
Secondary & 0.300 & 0.458 & 0 & 1 \\
Age & 41.237 & 16.333 & 15 & 101 \\
Employed & 0.543 & 0.498 & 0 & 1 \\
Unemployed & 0.078 & 0.269 & 0 & 1 \\
Married & 0.642 & 0.479 & 0 & 1 \\
Single & 0.238 & 0.426 & 0 & 1 \\
Medium Income & 0.370 & 0.483 & 0 & 1 \\
High Income & 0.292 & 0.455 & 0 & 1 \\
\hline \hline & & & & \\
\hline
\end{tabular}


Table 7

European Social Survey

\section{Summary Statistics, Second Generation Immigrants}

\begin{tabular}{lcccc}
\hline \hline & Mean & S.D. & Min & Max \\
\hline TV watching politics & 1.915 & 1.269 & 0 & 7 \\
News politics & 1.199 & 0.826 & 0 & 7 \\
Interested in politics & 2.413 & 0.912 & 1 & 4 \\
Generalized trust & 5.072 & 2.476 & 0 & 10 \\
Follow rules & 3.811 & 1.393 & 1 & 6 \\
Family ties & -0.167 & 0.344 & -0.917 & 0.498 \\
Age & 47.866 & 17.043 & 14 & 94 \\
Male & 0.447 & 0.497 & 0 & 1 \\
Married & 0.560 & 0.496 & 0 & 1 \\
Single & 0.214 & 0.410 & 0 & 1 \\
Primary & 0.141 & 0.348 & 0 & 1 \\
Secondary & 0.610 & 0.488 & 0 & 1 \\
Unemployed & 0.050 & 0.218 & 0 & 1 \\
Out of labor force & 0.528 & 0.499 & 0 & 1 \\
Family income & 5.905 & 2.953 & 1 & 12 \\
\hline \hline
\end{tabular}


Table 8

European Social Survey

Summary Statistics, Immigrants, by Country of Origin

\begin{tabular}{|c|c|c|c|c|c|c|c|c|c|c|c|c|c|}
\hline Country of origin & Obs. & TV & News & Inter. pol. & Trust & Rules & Fam. ties & Age & Male & Married & Primary & Unemp. & Fam. inc. \\
\hline AT & 95 & 1.89 & 1.18 & 2.64 & 5.42 & 3.85 & -0.39 & 54.3 & 0.39 & 0.55 & 0.07 & 0.01 & 6.86 \\
\hline $\mathrm{BE}$ & 72 & 1.75 & 1.08 & 2.12 & 5.30 & 3.49 & -0.17 & 47.2 & 0.47 & 0.43 & 0.13 & 0.06 & 7.31 \\
\hline BG & 43 & 2.34 & 1.38 & 2.32 & 4.09 & 4.16 & -0.02 & 43.1 & 0.32 & 0.70 & 0.32 & 0.09 & 4.42 \\
\hline BY & 109 & 1.73 & 1.05 & 2.22 & 4.61 & 4.16 & -0.65 & 50.9 & 0.27 & 0.44 & 0.06 & 0.03 & 3.14 \\
\hline CA & 13 & 2.15 & 1.37 & 2.53 & 6.38 & 3.30 & 0.34 & 43.1 & 0.69 & 0.54 & 0.08 & 0.08 & 6.92 \\
\hline $\mathrm{CZ}$ & 124 & 1.86 & 1.24 & 2.58 & 4.50 & 3.81 & -0.28 & 48.9 & 0.45 & 0.65 & 0.05 & 0.02 & 5.61 \\
\hline $\mathrm{DE}$ & 419 & 1.97 & 1.40 & 2.70 & 5.76 & 3.56 & -0.78 & 49.6 & 0.44 & 0.59 & 0.10 & 0.03 & 7.61 \\
\hline $\mathrm{DK}$ & 59 & 1.95 & 1.29 & 2.66 & 7.00 & 3.79 & -0.91 & 45.1 & 0.47 & 0.59 & 0.08 & 0.02 & 8.30 \\
\hline $\mathrm{EE}$ & 18 & 2.11 & 1.47 & 2.61 & 5.61 & 3.94 & -0.46 & 51.4 & 0.33 & 0.50 & 0.05 & 0.11 & 6.00 \\
\hline ES & 90 & 1.82 & 1.12 & 2.32 & 4.8 & 3.54 & 0.21 & 43.2 & 0.49 & 0.53 & 0.10 & 0.08 & 7.47 \\
\hline FI & 149 & 2.18 & 1.25 & 2.74 & 6.03 & 3.49 & -0.50 & 46.5 & 0.35 & 0.40 & 0.14 & 0.05 & 7.09 \\
\hline FR & 224 & 1.81 & 1.20 & 2.51 & 5.14 & 3.50 & -0.02 & 44.5 & 0.49 & 0.55 & 0.11 & 0.05 & 7.79 \\
\hline GB & 189 & 1.94 & 1.27 & 2.42 & 6.14 & 3.66 & -0.19 & 45.1 & 0.45 & 0.52 & 0.09 & 0.02 & 7.83 \\
\hline GR & 48 & 2.25 & 1.29 & 2.52 & 4.25 & 4.17 & -0.38 & 48.1 & 0.40 & 0.48 & 0.27 & 0.08 & 5.00 \\
\hline HR & 54 & 1.61 & 1.15 & 2.30 & 4.94 & 3.35 & -0.13 & 48.1 & 0.33 & 0.65 & 0.16 & 0.07 & 6.44 \\
\hline $\mathrm{HU}$ & 69 & 1.88 & 1.28 & 2.42 & 4.07 & 3.59 & -0.05 & 50.9 & 0.46 & 0.62 & 0.09 & 0.09 & 5.56 \\
\hline ID & 61 & 2.19 & 1.17 & 2.81 & 5.67 & 4.05 & 0.49 & 50.1 & 0.34 & 0.49 & 0.02 & 0.00 & 7.07 \\
\hline IE & 47 & 2.25 & 1.17 & 2.55 & 5.51 & 3.57 & 0.02 & 50.8 & 0.51 & 0.58 & 0.04 & 0.02 & 7.34 \\
\hline IN & 40 & 2.15 & 1.34 & 2.50 & 5.41 & 4.08 & 0.18 & 41.8 & 0.60 & 0.55 & 0.07 & 0.05 & 7.45 \\
\hline IT & 379 & 1.75 & 1.12 & 2.30 & 4.75 & 3.59 & 0.20 & 47.6 & 0.55 & 0.57 & 0.23 & 0.04 & 7.17 \\
\hline $\mathrm{KZ}$ & 17 & 2.06 & 0.66 & 2.17 & 4.76 & 3.75 & -0.19 & 42.82 & 0.47 & 0.76 & 0.00 & 0.06 & 4.47 \\
\hline LT & 37 & 1.97 & 1.11 & 2.13 & 5.00 & 4.19 & -0.83 & 46.54 & 0.40 & 0.51 & 0.08 & 0.05 & 4.10 \\
\hline LV & 21 & 1.52 & 1 & 2.14 & 5.04 & 3.29 & -0.19 & 42.61 & 0.29 & 0.43 & 0.09 & 0.00 & 3.52 \\
\hline NL & 95 & 2.06 & 1.28 & 2.43 & 5.51 & 3.48 & -0.74 & 49.87 & 0.53 & 0.75 & 0.16 & 0.03 & 7.95 \\
\hline PL & 216 & 1.86 & 1.20 & 2.39 & 4.98 & 3.75 & 0.21 & 46.67 & 0.43 & 0.49 & 0.05 & 0.07 & 6.25 \\
\hline
\end{tabular}




\begin{tabular}{lccccccccccccc}
\hline PT & 208 & 1.58 & 0.82 & 1.96 & 4.84 & 4.08 & 0.09 & 37.82 & 0.54 & 0.71 & 0.51 & 0.02 & 7.36 \\
RO & 105 & 1.90 & 1.15 & 2.58 & 4.49 & 3.80 & 0.11 & 45.3 & 0.44 & 0.63 & 0.10 & 0.09 & 5.41 \\
RU & 851 & 1.97 & 1.16 & 2.38 & 4.82 & 3.98 & -0.17 & 52.8 & 0.38 & 0.53 & 0.09 & 0.06 & 3.20 \\
SE & 52 & 1.90 & 1.26 & 2.58 & 6.73 & 4.10 & -0.64 & 48.1 & 0.27 & 0.46 & 0.02 & 0.04 & 8.2 \\
SK & 87 & 1.86 & 1.24 & 2.11 & 4.31 & 4.04 & -0.12 & 48.3 & 0.55 & 0.52 & 0.07 & 0.14 & 4.57 \\
TR & 280 & 1.97 & 1.20 & 2.26 & 4.26 & 4.26 & 0.17 & 44.8 & 0.52 & 0.65 & 0.36 & 0.09 & 5.48 \\
UA & 180 & 1.93 & 1.14 & 2.36 & 4.84 & 3.91 & -0.13 & 46.3 & 0.44 & 0.55 & 0.04 & 0.05 & 3.37 \\
\hline
\end{tabular}

